\title{
Hydrogeology of the Southwestern Part of the Town of Hempstead, Nassau County, New York
}

U.S. GEOLOGICAL SURVEY

Water-Resources Investigations

Report 85-4288

REVISED

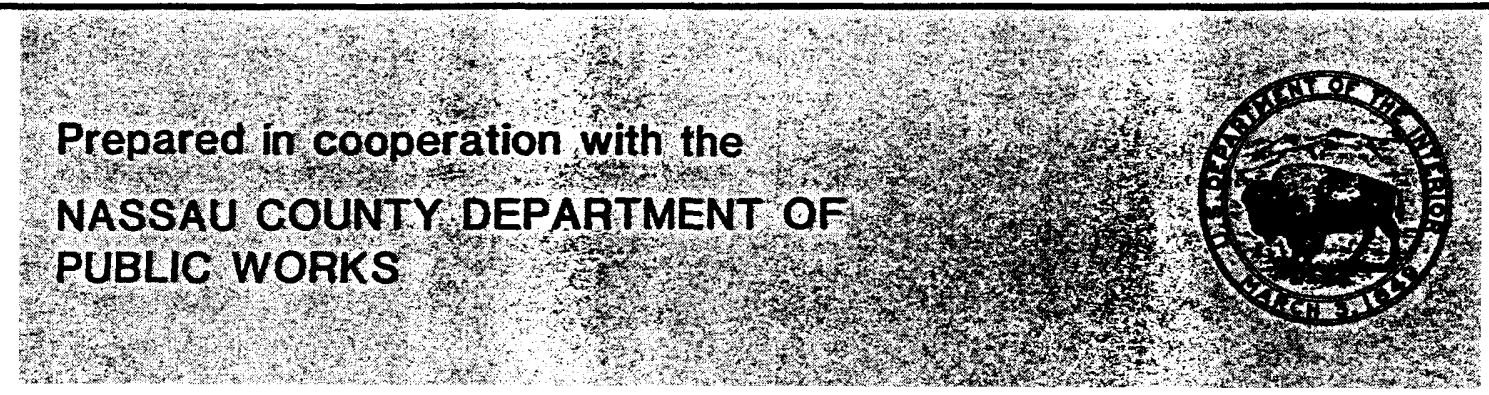


HYDROGEOLOGY OF THE SOUTHWESTERN PART OF THE

TOWN OF HEMPSTEAD, NASSAU COUNTY, NEW YORK

by Richard K. Krulikas

U.S. GEOLOGICAL SURVEY

Water-Resources Investigations Report 85-4288

Prepared in cooperation with the

NASSAU COUNTY DEPARTMENT OF PUBLIC WORKS

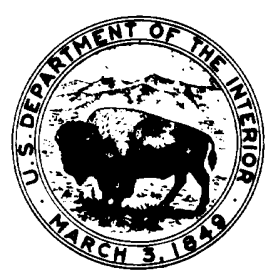

Syosset, New York

Revised 1989 
UNITED STATES DEPARTMENT OF THE INTERIOR

DONALD PAUL HODEL, Secretary

GEOLOGICAL SURVEY

Dallas L. Peck, Director

For additional information write to:

U.S. Geological Survey

5 Aerial Way

Syosset, New York 11791
Copies of this report may be purchased from:

U.S. Geological Survey Books and Open-File Reports Section Federal Center, B1dg. 41

Box 25425

Denver, CO 80225

(303) 236-7476 


\section{CONTENTS}

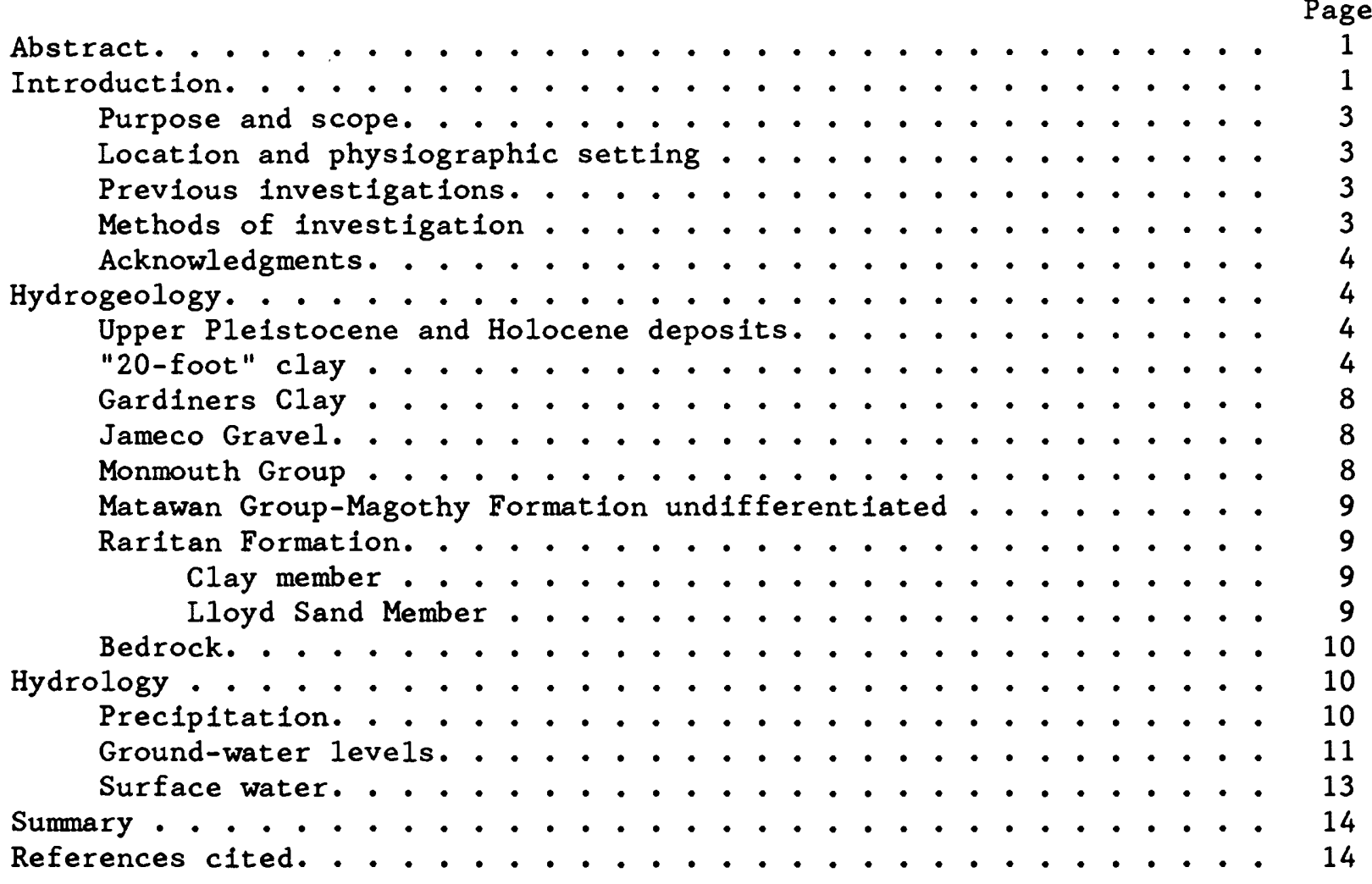

\section{ILLUSTRATIONS}

Figure 1. Map showing location of southwestern part of Town of

Hempstead . . . . . . . . . . . . . . . . . .

2

2. Graphs showing annual and average monthly precipitation at Valley Stream (1927-83) . . . . . . . . . . .

3. Hydrographs for wells N1116, N1141, N1440, and N1455, 1960-84 . . . . . . . . . . . . . . . . .

\section{TABLES}

Table 1. Stratigraphic and correlative hydrologic units underlying southwestern part of Town of Hempstead. . . . . . . . .

2. Depth, altitude, and geologic formations penetrated at selected wells and test holes in southwestern part of Town of Hempstead . . . . . . . . . . . . . . . . .

3. Discharges of selected streams in southwestern part of Town of Hempstead . . . . . . . . . . . . . . . . . 


\section{PLATES}

(in pocket)

Plates 1-5. Maps of southwestern part of Town of Hempstead showing:

1. A. Location of wells and streamflow-measurement sites and geologic sections shown in plate 6

B. Inferred extent, altitude, and configuration of top of "20-foot" clay

2. A. Inferred extent, altitude, and configuration of top of Gardiners Clay

B. Inferred extent, altitude, and configuration of top of Monmouth Group and Jameco Gravel

3. A. Altitude and configuration of top of Matawan GroupMagothy Formation, undifferentiated

B. Altitude and configuration of top of the clay member of the Raritan Formation

4. A. Altitude and configuration of top of Lloyd Sand Member of the Raritan Formation

B. Water-Table altitude in southwestern part of Town of Hempstead, April 1984

5. A. Potentiometric surface of Magothy aquifer in southwestern part of Town of Hempstead, April 1984

B. Potentiometric surface of Lloyd aquifer in southwestern part of Town of Hempstead, January 1984

6. Hydrogeologic sections in southwestern part of Town of Hempstead

\section{CONVERSION FACTORS AND ABBREVIATIONS}

The following conversion factors are given for readers who prefer to use metric (International System) units rather than the inch-pound units used in this report.

Multip1y

inch (in.)

foot ( $f t)$

$\mathrm{mile}(\mathrm{mi})$

square mile $\left(\mathrm{mi}^{2}\right)$ by

$$
\begin{gathered}
25.40 \\
0.3048 \\
1.609 \\
2.590
\end{gathered}
$$

\section{To obtain}

millimeter (mm)

meter $(\mathrm{m})$

kilometer $(\mathrm{km})$

square kilometer $\left(\mathrm{km}^{2}\right)$ 


\title{
HYDROGEOLOGY OF THE SOUTHWESTERN PART OF THE \\ TOWN OF HEMPSTEAD, NASSAU COUNTY, NEW YORK
}

\author{
By Richard K. Krulikas
}

\begin{abstract}
The ground-water resources of the southwestern part of the Town of Hempstead, Nassau County, were investigated in 1984. The area studied encompasses 85 square miles, or 68 percent of the town's 125-square-mile area.

The ground-water reservoir underlying the area consists of deposits of unconsolidated gravel, sand, silt, and clay of Holocene, Pleistocene, and Late Cretaceous age that have been divided into eight geologic units. The maximum total thickness of the unconsolidated deposits is about 1,500 feet. Precipitation is the sole source of ground-water recharge in the area. The long-term average annual precipitation during 1927-83 was 42.62 inches, as recorded at the Valley Stream weather station.

The report presents 10 maps showing altitudes of the tops of the geologic units and the potentiometric surfaces of the three major aquifers. Also included are six geologic sections, four hydrographs, and several graphs presenting the data that were collected.
\end{abstract}

\section{INTRODUCTION}

The increasing use of ground water for public supply, industrial use, and commercial use within Nassau County has brought about a need for detailed knowledge of the hydrogeologic framework of the ground-water system. To facilitate proper development and management decisions for the conservation of the ground-water supply, which is the county's sole source of freshwater, the hydrogeologic characteristics of the aquifers must be thoroughly understood.

As part of a continuing cooperative study between the U.S. Geological Survey and the Nassau County Department of Public Works to document the hydrogeology of Nassau County, the Geological Survey in 1984 compiled data on the geologic framework of the southwestern part of the Town of Hempstead and the hydrogeologic units that form the ground-water reservoir in that area, to provide a basis for future hydrologic studies. 


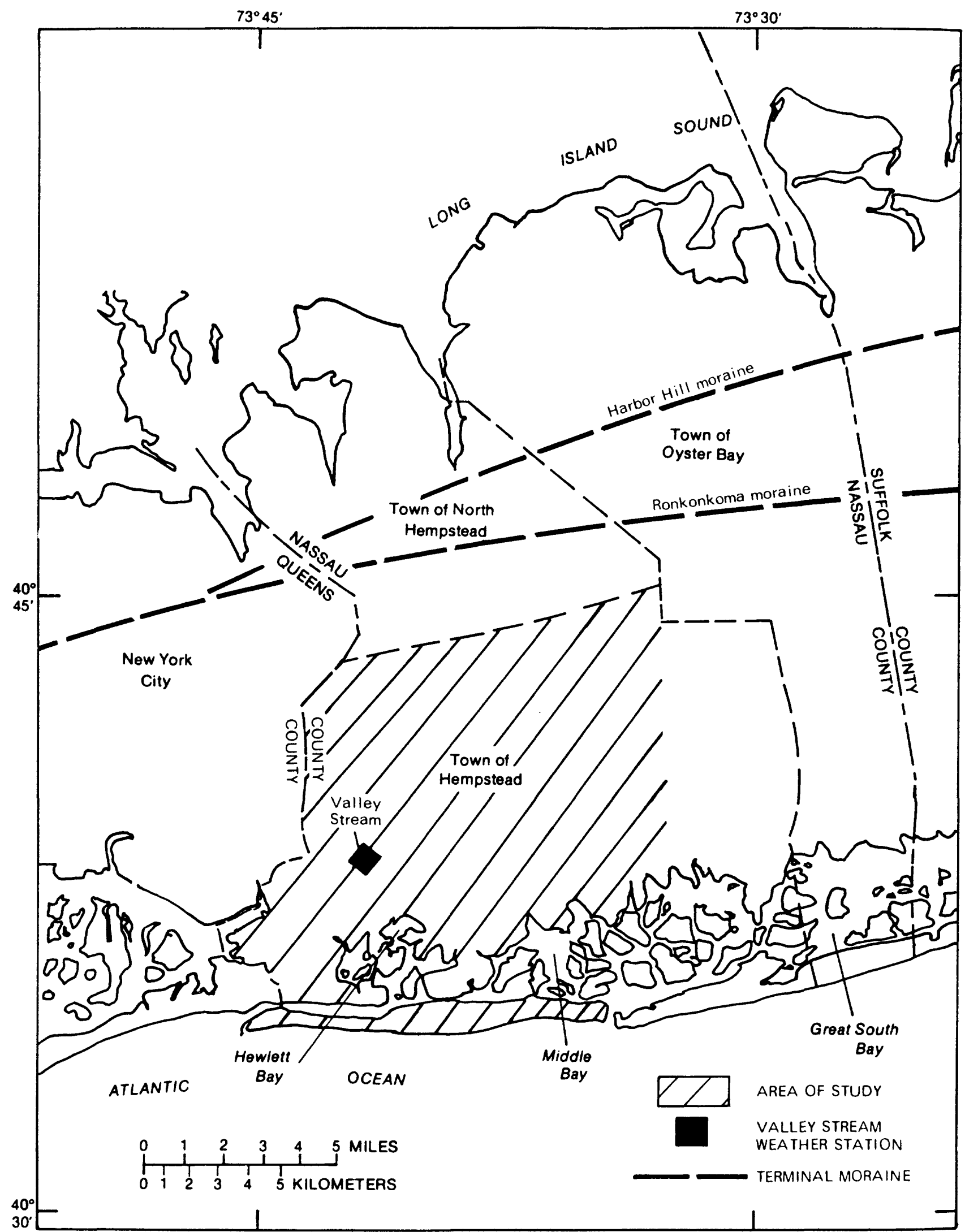

Base from U.S. Geological

Survey, New York, 1960.

Figure 1.--Location of southwesterm part of Town of Hempstead, Nassau County, N.Y. 


\section{Purpose and Scope}

This report presents maps and geologic sections that summarize hydrologic and geologic data on the occurrence and movement of ground water in the area of investigation. Included are a water-table map of the upper glacial aquifer, potentiometric-surface maps of the the Magothy and Lloyd aquifers, several generalized structure-contour maps, and six geologic sections with geologic logs. Also included are precipitation graphs and hydrographs of selected we11s.

\section{Location and Physiographic Sotting}

The area studied lies between $73^{\circ} 35^{\circ}$ and $73^{\circ} 46^{\circ}$ west longitude and between $40^{\circ} 35^{\circ}$ and $40^{\circ} 45^{\circ}$ north latitude in the southwestern third of Nassau County (fig. 1). It contains approximately $85 \mathrm{mi}^{2}$, or 68 percent of the town's $125-\mathrm{mi}^{2}$ area. The area lies entirely on an outwash plain, which extends about $10 \mathrm{mi}$ southward from near the Ronkonkoma and Harbor Hill terminal moraines to the south shore of Long Island. The inland area is suburban; the south-shore area is characterized by swamps and lagoons that border Hewlett and Middle Bays, which are contained by the south-shore barrier island (fig. 1). The beaches rise to as much as $20 \mathrm{ft}$ above sea level and range from a few tenths of a mile to $1 \mathrm{mi}$ wide.

\section{Provious Investigations}

The geology and ground-water resources of Long Island were described by Veatch and others (1906), Fuller (1914), and Suter and others (1949). These reports are islandwide in scope and contain information on the southwestern part of the Town of Hempstead. Detailed studies of the geology and hydrology of Nassau County were made more recently by Perlmutter and Geraghty (1963), Swarzenski (1963), Isbister (1966), and $\mathrm{Ku}$ and others (1975). The most recent water-table maps that include this area are those by Koszalka (1975) for 1974; Nakao and Erlichman (1978) for 1975, Donaldson and Koszalka (1982) for 1979, and Doriski (in press) for 1983.

Additional publications detailing the hydrology of the area are Cohen, Franke and McClymonds (1969), which discusses effects of the 1962-66 drought; and Donaldson and Koszalka (1982), which depicts the 1979 potentiometric surface of both the Magothy and Lloyd aquifers. Some of the streamflow data presented in this report have been published by the U.S. Geological Survey (1981, 1982, 1983).

\section{Mothods of Investigation}

This report was prepared from information obtained through previous studies and from county and State agencies. All data are on file at the U.S. Geological Survey's Long Island office in Syosset, N.Y.

Data on well construction and geology were obtained from New York State Department of Environmental Conservation in Stony Brook. Water-level data that were used to compile the water-table map were provided by the Division of Sanitation and Water Supply of the Nassau County Department of Public Works; 
data that were used to construct the potentiometric-surface maps of the Magothy and Lloyd aquifers were derived from field measurements made by the U.S. Geological Survey.

\section{Acknow ledgments}

This report was prepared in cooperation with the Nassau County Department of Public Works. Special thanks are extended to Robert J. O'Reilly of the New York State Department of Environmental Conservation, and Ralph Denton of the Nassau County Department of Public Works, Water Supply Unit, for making records of wells and other essential data available.

\section{HYDROGEOLOGY}

We11 locations are shown on plate 1A, and six geologic sections are shown on plate 6. Al1 wells and test borings used in the sections are listed in table 2 (p. 6), which also gives land-surface altitude, well depth, and hydrogeologic contacts of formation penetrated. The geologic units that form the ground-water reservoir on Long Island and their stratigraphic relationships are summarized in table 1. The following paragraphs describe the composition, extent, and altitude of the units in order of youngest to oldest.

\section{Upper Ploistocene and Holocene Deposits}

The upper Pleistocene and Holocene (recent) deposits together form the upper glacial aquifer, which was the major source of public supply in this area before the 1960 's. These deposits have a maximum thickness of about 180 ft and lie on top of the Gardiners Clay and, where the Gardiners Clay and Jameco Gravel are missing, on top of the Matawan Group-Magothy Formation. In other areas, the upper Pleistocene and Holocene deposits rest directly upon the Jameco or, as in the southern part of the study area, are separated into an upper and lower part by the "20-foot" clay. (See hydrogeologic sections on p1.6.)

The upper deposits consist mainly of stratified beds of fine to coarse sand and of sand and gravel; thin beds of silt and clay are interbedded with coarse-grained material. The outwash that constitutes the bulk of the upper Pleistocene deposits is yellow and brown or, in some places, gray. The sand and gravel consist mainly of iron-stained quartz but include particles of biotite, chlorite, hornblende, and igneous and metamorphic rocks.

The Holocene deposits, which form a thin layer in the upper few feet, lie beneath the bays, in marshlands, on barrier beaches, and along streams. They are too thin to be differentiated in the geologic sections on plate 6 .

\section{"20-Foot" Clay}

The "20-foot" clay is a marine deposit within the upper Pleistocene deposits near the south shore. The clay is lithologically similar to the underlying Gardiners Clay, with the same mineral assemblage and fossils. The 
Table 1.--Stratigraphic and correlative hydrologic units underlying the southwestern part of the Town of Hempstead.

[Modifled from Dortsk1 and W11de-Katz, 1983]

\begin{tabular}{|c|c|c|c|c|c|}
\hline Systrm & Series & Age & \multicolumn{2}{|c|}{ Stratigraphic Unit } & $\begin{array}{c}\text { Hydrostratigraphic } \\
\text { Unit }\end{array}$ \\
\hline \multirow{5}{*}{ QUATERNARY } & Holocene & Postglactal & \multicolumn{2}{|c|}{$\begin{array}{c}\text { Holoceue (recent) } \\
\text { deposits }\end{array}$} & \multirow{3}{*}{$\begin{array}{l}\text { "20-foot" clay } \\
\text { Upper glacial } \\
\text { aquifer }\end{array}$} \\
\hline & \multirow{4}{*}{ Pleistocene } & $\begin{array}{c}\text { Wisconsin } \\
\text { (upper } \\
\text { Pleistocene) }\end{array}$ & \multirow{2}{*}{\multicolumn{2}{|c|}{$\begin{array}{l}\text { Upper } \\
\text { Pleistocene } \\
\text { deposits } \\
\text { "20-foot" clay } \\
\text { Upper Pleistocene } \\
\text { deposits }\end{array}$}} & \\
\hline & & & & & \\
\hline & & Sangamon & \multicolumn{2}{|c|}{ Gardiners Clay } & Gardiners Clay \\
\hline & & Pre-Sangamon & \multicolumn{2}{|c|}{$\begin{array}{l}\text { - unconformity- } \\
\text { Jameco Gravel } 1\end{array}$} & Jameco aquifer ${ }^{1}$ \\
\hline & & Pre-Sangamon & \multicolumn{2}{|c|}{$\begin{array}{c}\text { Reworked Matawan- } \\
\text { Magothy channel } \\
\text { deposits }\end{array}$} & $\begin{array}{l}\text { Upper glacial or } \\
\text { Magothy aquifer }\end{array}$ \\
\hline \multirow{5}{*}{ CRETACEOUS } & \multirow{5}{*}{$\begin{array}{l}\text { Upper } \\
\text { Cretaceous }\end{array}$} & & \multicolumn{2}{|c|}{$\begin{array}{l}\text { Moumouth } \\
\text { Group } \\
\text { nconf ormi ty }\end{array}$} & $\begin{array}{l}\text { Monmouth } \\
\text { greensand }\end{array}$ \\
\hline & & & \multicolumn{2}{|c|}{$\begin{array}{l}\text { Matawan Group- } \\
\text { Magothy Formatiou, } \\
\text { undifferentiated }\end{array}$} & $\begin{array}{l}\text { Magothy } \\
\text { aquifer }\end{array}$ \\
\hline & & & \multicolumn{2}{|c|}{ ___ unconformity } & \\
\hline & & & \multirow[t]{2}{*}{$\begin{array}{l}\text { Raritan } \\
\text { Formation }\end{array}$} & $\begin{array}{l}\text { Untuamed } \\
\text { clay } \\
\text { member }\end{array}$ & $\begin{array}{c}\text { Raritan } \\
\text { confining unit }\end{array}$ \\
\hline & & & & $\begin{array}{l}\text { Lloyd } \\
\text { Saud } \\
\text { Member }\end{array}$ & Lloyd aquifer \\
\hline \multicolumn{3}{|c|}{$\begin{array}{l}\text { Paleozolc (or) } \\
\text { Precambrian }\end{array}$} & \multicolumn{2}{|c|}{ Bedrock } & $\begin{array}{l}\text { Relatively } \\
\text { impermeable } \\
\text { bed rock }\end{array}$ \\
\hline
\end{tabular}

1Present In Nassau County only 


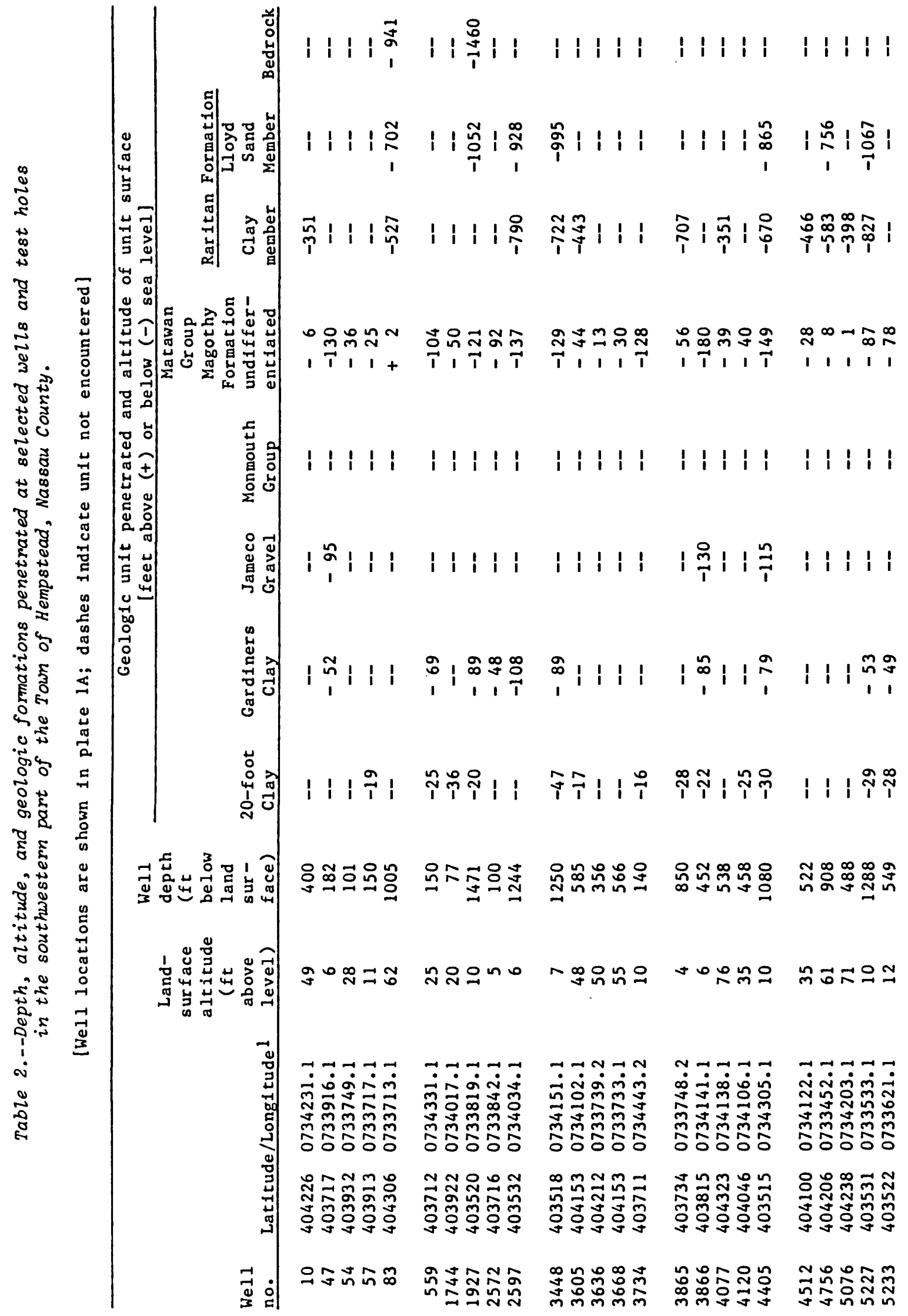




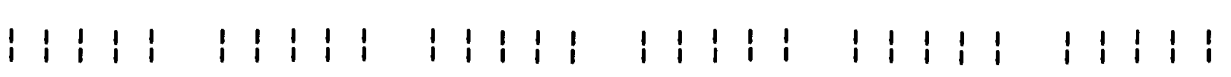

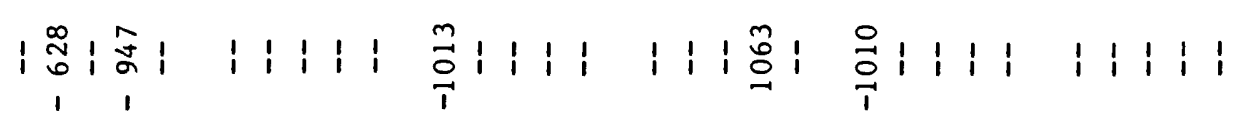

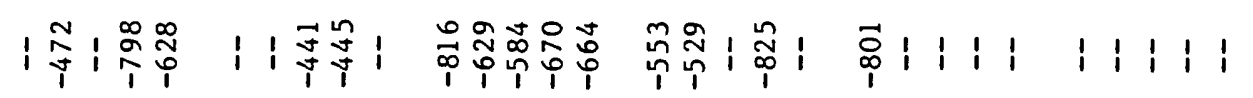

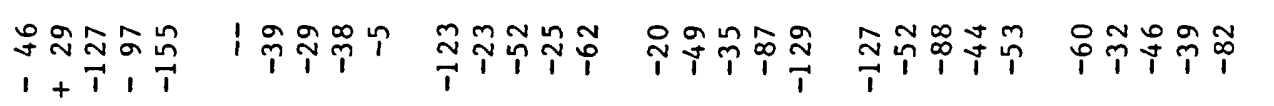

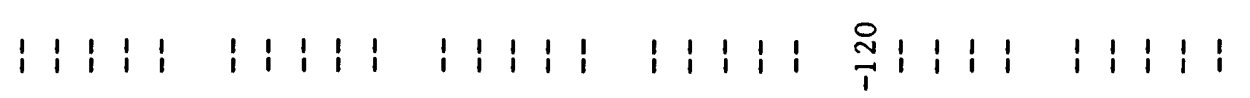
$1111 \stackrel{2}{1} 1111191111911119111191111$

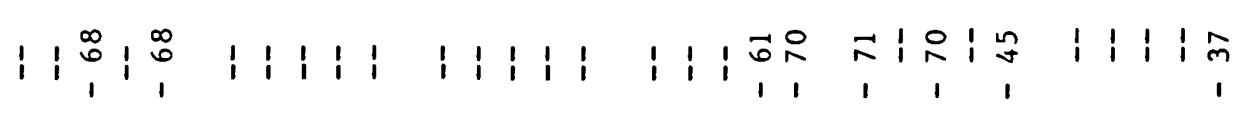

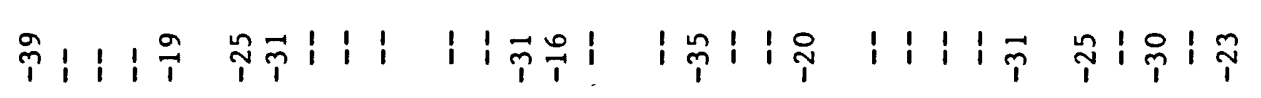

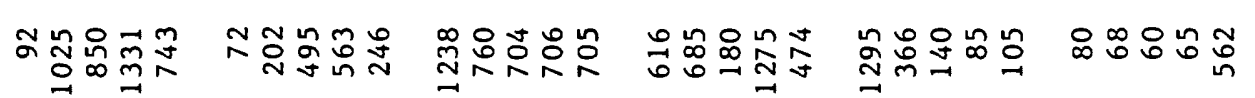

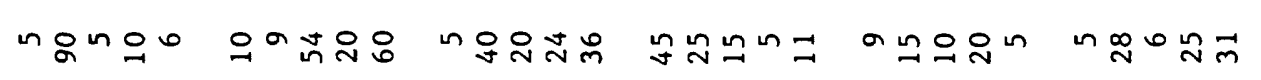

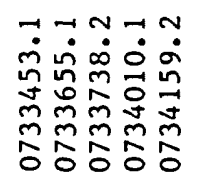

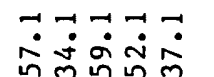

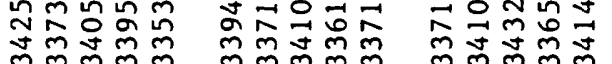

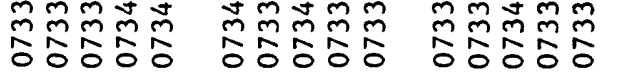

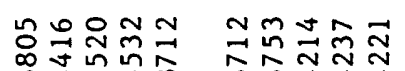

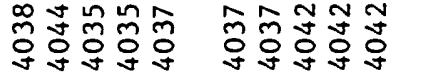

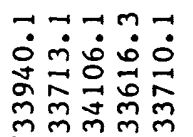
mలmmm

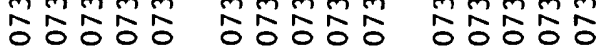

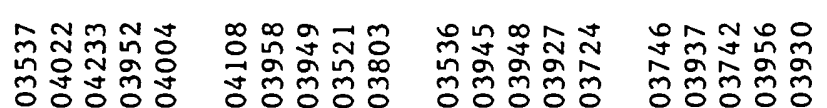

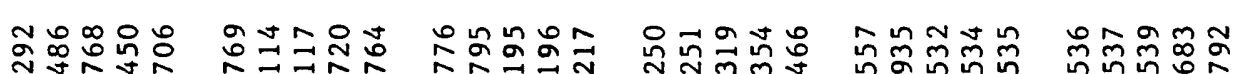

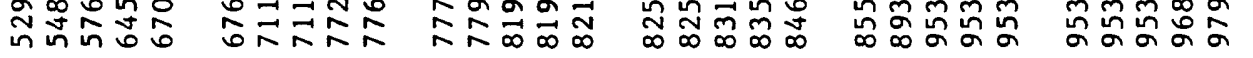


two units are distinguished primarily by stratigraphic position. The "20-foot" clay is separated from the Gardiners Clay by 15 to $40 \mathrm{ft}$ of upper Pleistocene deposits in western Nassau County; eastward the separation is considerably less, which makes the correlations more tentative.

The upper-surface altitude of the clay ranges from 15 to $45 \mathrm{ft}$ below sea leve1 (p1. 1B); thickness ranges from 0 at the northern limit to $30 \mathrm{ft}$ at the barrier islands. (See hydrogeologic sections on $\mathrm{p} 1.6$. ) In many places, the unit overlies upper Pleistocene deposits that range in thickness from 0 to 40 ft; it directly overlies the Matawan Group-Magothy Formation or Gardiners Clay at several locations where the underlying Pleistocene deposits have been removed by erosion. The "20-foot" clay is overlain by upper Pleistocene deposits (Perlmutter and Geraghty, 1963; Doriski and Wilde-Katz 1983). (See hydrogeologic sections on 1.6. )

\section{Gardiners Clay}

The Gardiners Clay is a marine deposit beneath the south shore of Long Island. The unit is typically grayish-green to gray and contains a few sand and silt beds. The mineral assemblage contains glauconite, quartz, muscovite, biotite, pyroxene, amphibole, and a complete clay mineral suite of illite, chlorite, mixed-layer clays, and minor kaolinite (Lonnie, 1982). The clay also contains diatoms, foraminifera, shell fragments of pelecypods and gastropods, and peat. A more detailed discussion of the Gardiners Clay is given in Perlmutter and Geraghty (1963, p. A32-A35) and Doriski and Wilde-Katz (1983, p. 6-7). Its upper surface altitude ranges from 40 to $110 \mathrm{ft}$ below sea leve1 ( $\mathrm{p} 1.2 \mathrm{~A}$ ), and thickness ranges from $0 \mathrm{ft}$ at the northern limit to $90 \mathrm{ft}$ at the barrier islands. (See hydrogeologic sections in pl. 6.)

\section{Jameco Gravel}

The Jameco Gravel is an irregular body of predominantly coarse sand and gravel deposited on the eroded surface of the Matawan Group-Magothy Formation. It was probably deposited as outwash by glacial meltwater streams during pre-Wisconsin time. The unit is typically a dark-brown and dark-gray granule to cobble gravel. A more detailed lithologic description and depositional history are given in Soren (1978).

The Jameco Gravel is primarily in Queens County but extends into the extreme southwestern part of Nassau County, where its upper surface altitude ranges from 80 to $140 \mathrm{ft}$ below sea level (fig. 2B), and thickness ranges from 0 to $50 \mathrm{ft}$. (See hydrogeologic sections $A-A^{\prime}, B-B^{\prime}$, and $E-E^{\prime}$ in $p 1.6$. )

\section{Monmouth Group}

The Monmouth Group is a marine deposit of Cretaceous age that occurs beneath the barrier islands, primarily in Suffolk County. Only one well along the barrier beach (N8557) penetrates the Monmouth Group. (See p1. 2B and hydrogeologic section $A-A^{\prime}$ in $\left.\mathrm{p} 1.6.\right)$ The Monmouth Group is typically a greenish-black glauconitic and lignitic clay, silt, or clayey to silty sand. A more detailed lithologic description of the Monmouth Group is given in 
Jensen and Soren (1974). Its upper-surface altitude is approximately $120 \mathrm{ft}$ below sea level in the study area but may range from 70 to $165 \mathrm{ft}$ below sea leve1 (Doriski and Wilde-Katz, 1983) farther east along the barrier islands.

\section{Matawan Group-Magothy Formation, Undifferentiated}

The Matawan Group-Magothy Formation, undifferentiated, forms the Magothy aquifer of Long Island, the major source of public supply in the area. This unit consists of beds and lenses of light-gray, fine to coarse sand with some clay. Detailed lithologic descriptions are given in Soren (1978); Ku and others (1975); and Jensen and Soren (1974).

The upper surface of the Matawan Group-Magothy Formation, undifferentiated ( $\mathrm{pl} .3 \mathrm{~A}$ ) is not planar, in contrast to the surfaces of the underlying units. The surface was deeply eroded during Tertiary time and probably also in Pleistocene time. The upper-surface altitude of the unit ranges from as high as $50 \mathrm{ft}$ above sea level in the northeastern part of the study area to as low as $200 \mathrm{ft}$ below sea level in the southwestern part. The unit ranges in thickness from $350 \mathrm{ft}$ in the northern part to as much as $800 \mathrm{ft}$ in the southern part of the barrier islands. (See hyarogeologic sections on p1. 6.)

\section{Raritan Formation}

\section{Clay Nember}

The clay member of the Raritan Formation (commonly referred to as the Raritan clay) overlies the Lloyd Sand Member in the study area. The Raritan clay consists mainly of light to dark-gray, red, white, and yellow clay and varying amounts of silt and clayey and silty fine sand. Sandy beds of varying thicknesses are common. The upper altitude of the unit ranges from about 350 ft below sea level in the northwestern part of the study area to about $850 \mathrm{ft}$ below sea level in the southeastern part on the barrier islands (p1. 3B). The thickness increases to the southeast and ranges from about $150 \mathrm{ft}$ in the northwestern part to about $250 \mathrm{ft}$ in the southeastern part. (See hydrogeologic sections on $\mathrm{p} 1.6$.

The Raritan clay is significant because it confines water in the underlying Lloyd aquifer. Although the hydraulic conductivity of the Raritan clay is very low, it does not entirely prevent movement of water downward from the Magothy aquifer to the Lloyd aquifer. Some public-supply wells and other wells produce some of their water from sandy zones in the upper part of the Raritan clay.

\section{Lloyd Sand Member}

The Lloyd Sand Member of the Raritan Formation of Late Cretaceous age (Cohen and others, 1969, p. 18) is referred to as the Lloyd aquifer on Long Island. This unit consists of discontinuous layers of gravel, sand, sandy clay, silt and clay, and lies roughly parallel to the bedrock surface at depths ranging from about $450 \mathrm{ft}$ below sea level in the northwestern corner of 
the area to about $1,050 \mathrm{ft}$ below sea level in the southeastern corner of the barrier islands ( $\mathrm{pl}$. 4A). The unit's thickness ranges from $250 \mathrm{ft}$ in the northwest to $400 \mathrm{ft}$ in the southeast. (See hydrogeologic sections $A-A^{\prime}, D_{-} D^{\prime}$, and $\mathrm{F}-\mathrm{F}^{\prime}$ on $\mathrm{pl}$. 6.) Seventeen wells have penetrated the unit in the study area, but 10 are on the barrier beach, where the Lloyd aquifer is used as the major source of water by the Long Beach and Lido Beach Water Districts.

\section{Bedrock}

Bedrock of early Paleozolc and(or) Precambrian age underlies all of western Long Island (Fisher and others, 1962). The bedrock generally consists of metamorphic and igneous crystalline rocks, and its surface lies at depths of about $700 \mathrm{ft}$ below sea level in the northwestern corner of the area and dips uniformly to about 1,500 ft below sea level in the southeastern part on the barrier islands. (See hydrogeologic sections $A-A^{\prime}, D_{-}-D^{\prime}$, and $F-F^{\prime}$ in p1. 6.)

\section{HYDROLOGY}

Precipitation is the sole source of freshwater in Nassau County. Recharge to the ground-water reservoir results from infiltration of precipitation through the surficial deposits to the water table. The amount of water that reaches the water table varies throughout the year and is controlled by (1) type, frequency, and intensity of precipitation; (2) slope of the land surface; (3) soil-type, soll-moisture content, and the amount and kind of vegetation; and (4) air temperature.

\section{Precipitation}

The climate of the southwestern part of the Town of Hempstead is influenced by the Atlantic Ocean and is characterized by a moderate temperature range and mild winters. Precipitation falls in almost the same total amount in the cool season as during the warm season but is more frequent in spring than in fall. Most precipitation on Long Island is in the form of rain; only 5 to 10 percent is in the form of snow or sleet. Long-term precipitation in Nassau County averages 42 inches per year, as determined from 30 years of records collected by the National Weather Service.

The precipitation regime of Long Island for 1951-65 was studied by Miller and Frederick (1969), who calculated the mean annual precipitation in the southwestern part of the Town of Hemptead to be between 41 and 45 inches. This compares closely with the 42 inches per year determined for all of Nassau County. The annual precipitation recorded at Valley Stream by the Long Island Water Corporation during 1927-83 had a maximum of 63.74 inches in 1983 and a minimum of 24.83 inches in 1965 ( $\mathrm{fig}$. 2A); the long-term average annual precipitation during $1927-83$ is 42.62 inches. Mean monthly precipitation at Valley Stream ranges from a low of 2.96 inches in February to a high of 4.11 inches in August (fig. 2B). 


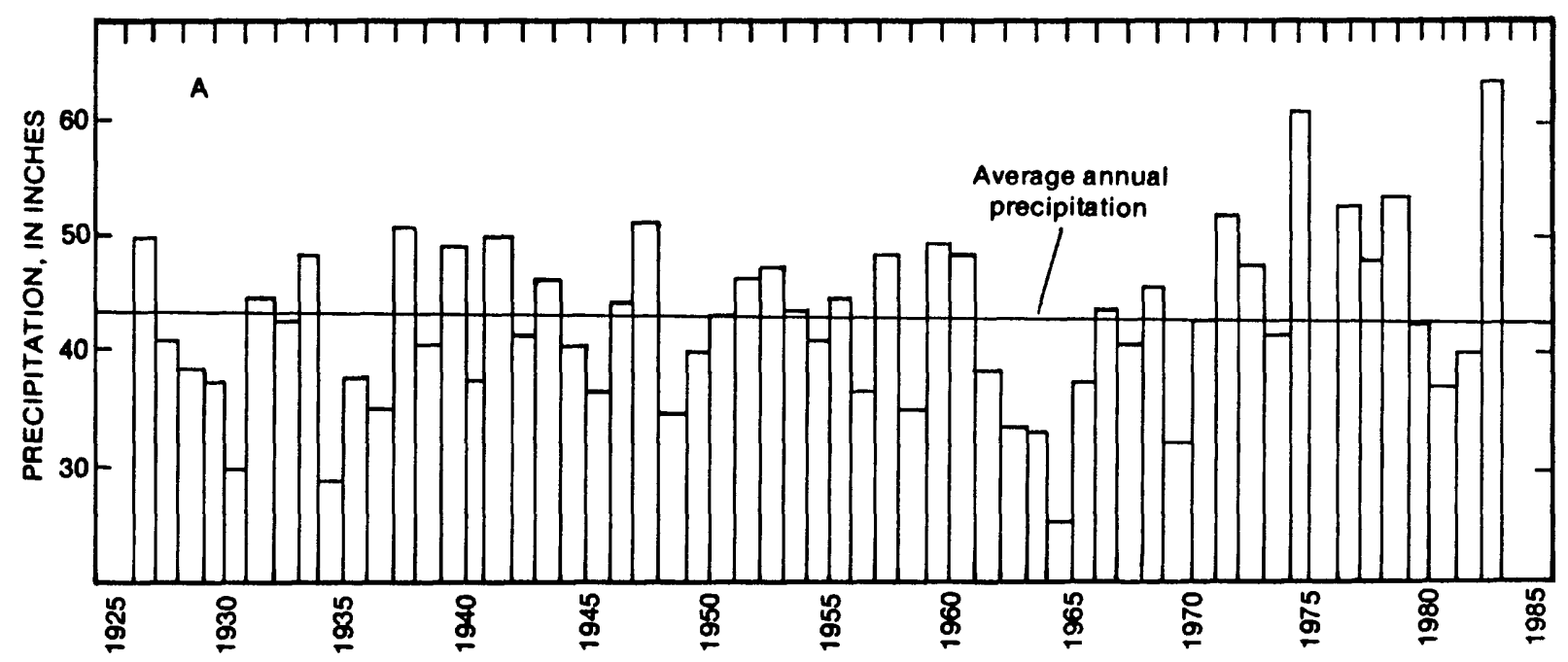

Figure 2 .

Precipitation at Valley Stream.

A. Annual precipitation, 1927-83.

$B$. Average monthly values.

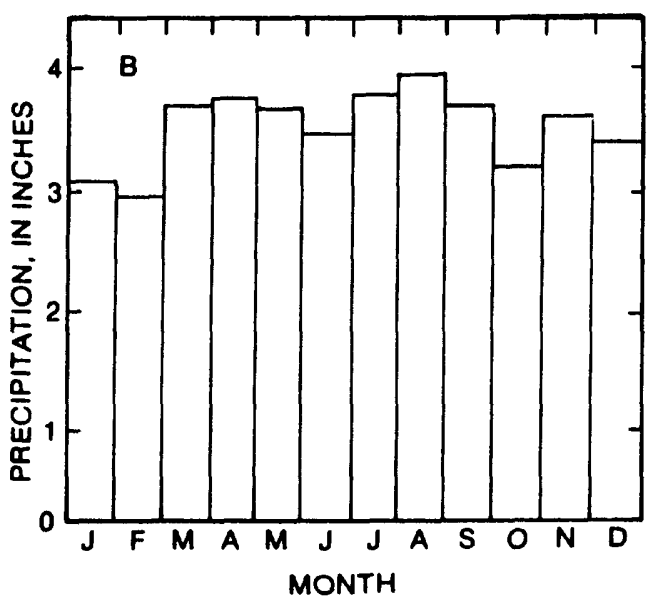

\section{Ground-Water Lovels}

Water-level measurements made in April 1984 at 114 observation wells in the upper glacial aquifer were used to prepare a water-table map of the southwestern part of the Town of Hempstead (p1. 4B). The water table has a maximum altitude in the northeastern part of the area; the water-table altitude decreases to sea level along the southern shore.

A potentiometric-surface map of the Magothy aquifer was prepared from water-level measurements made at 39 wells in April 1984 (p1. 5A). The potentiometric surface represents the static head. (The static head is the level to which water would rise in a tightly cased well that is screened at a specific depth.) The potentiometric surface of the Magothy aquifer also has its maximum altitude in the northeastern part of the study area; the potentiometric-surface altitude decreases to $5 \mathrm{ft}$ below sea level along the southwestern shore.

A potentiometric-surface map of the Lloyd aquifer was prepared from water-level measurements collected at six wells in January 1984 (p1. 5A) and from data given in Donaldson and Koszalka (1982). 
The U.S. Geological Survey has monitored several observation wells in the study area since the early 1930's. Figure 3 depicts hydrographs from four water-table wells (locations shown on pl. 4B). During the 1962-66 drought, water levels declined 10 to $15 \mathrm{ft}$ to the north (we11 N1141) and 3 to $5 \mathrm{ft}$ to the south and along the southern shore (we11 N1116). The data are not sufficient to determine any long-term trends in water levels since the 1962-66 drought.
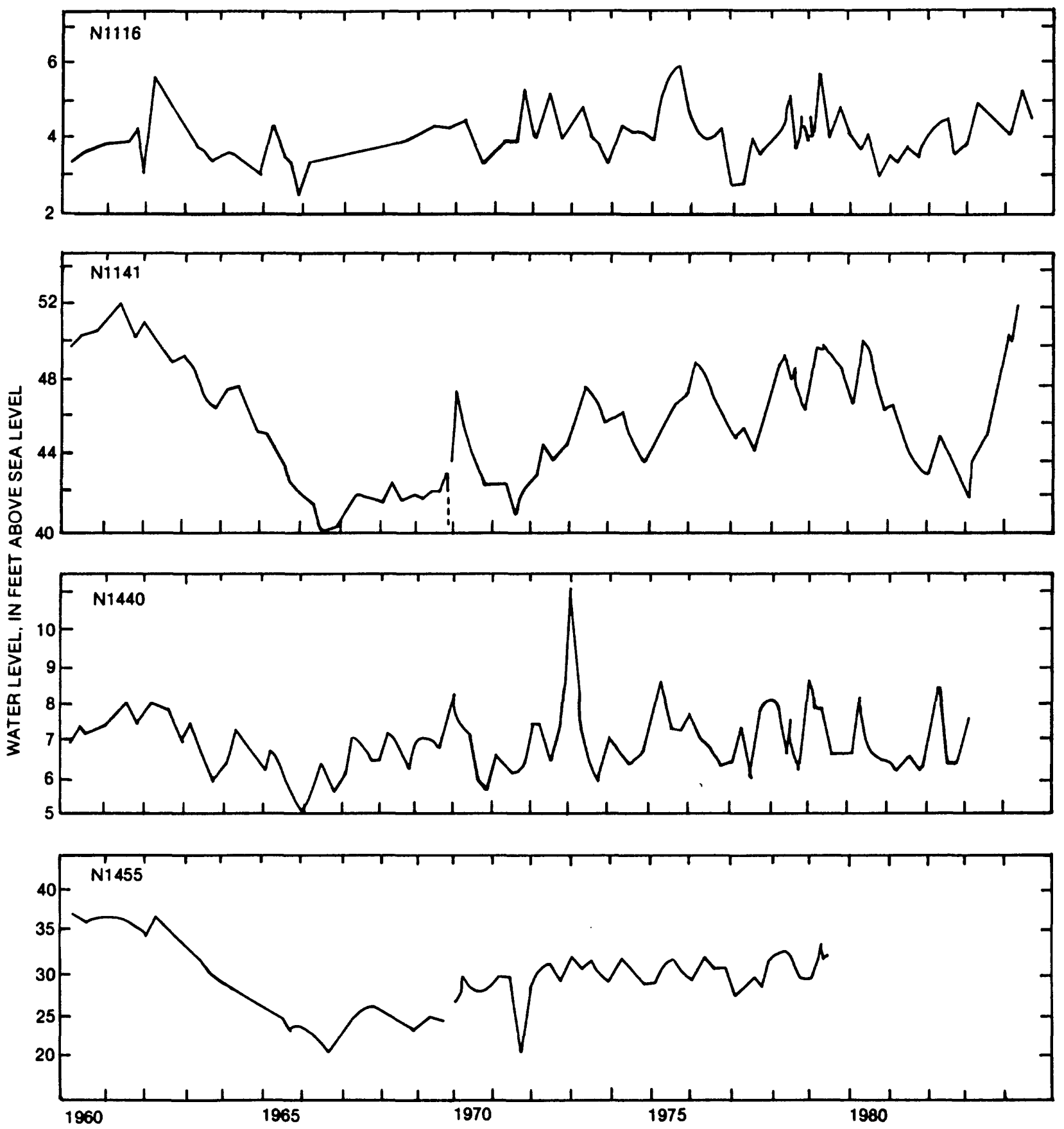

Figure 3.--Hydrographs for wells N1116, N1141,N1440, and N1455, $1960-84$. (Locations are shown in pl. $4 B$. ) 


\section{Surface Water}

All streams within the area studied (table 3 ) flow southward either into Hewlett Bay or Middle Bay ( $p 1$. 1). The area also has several natural lakes and ponds; many are kettleholes that intersect the water table, and some are perched. In addition, several ponds have been created behind small dams in some of the tributaries.

Table 3.--Discharges of selected streams in the southwestern part of the Town of Hempstead, N.Y.

[Locations are shown in pl. 1]

\begin{tabular}{|c|c|c|c|c|}
\hline $\begin{array}{l}\text { Station } \\
\text { no. }\end{array}$ & Station name & Location & Date & $\begin{array}{c}\text { Discharge } \\
\left(\mathrm{ft}^{3} / \mathrm{s}\right)\end{array}$ \\
\hline 01310600 & $\begin{array}{l}\text { Milburn Creek at } \\
\text { Baldwin }\end{array}$ & $\begin{array}{l}\text { Lat } 40^{\circ} 39^{\prime} 04^{\prime \prime}, \text { long } 73^{\circ} 36^{\prime} 13^{\prime \prime} \text {, } \\
\text { Nassau County, } 50 \mathrm{ft} \text { down- } \\
\text { stream from bridge on State } \\
\text { Highway } 27 \mathrm{~A}, 0.5 \mathrm{mi} \text { east of } \\
\text { Baldwin. }\end{array}$ & $\begin{array}{r}12-17-81 \\
3-2-82 \\
9-14-82 \\
1-25-83 \\
4-5-83 \\
7-18-83 \\
9-23-83\end{array}$ & $\begin{array}{l}6.2 \\
6.0 \\
4.1 \\
5.4 \\
8.1 \\
5.2 \\
4.8\end{array}$ \\
\hline 01310700 & $\begin{array}{l}\text { Parsonage Creek at } \\
\text { Baldwin }\end{array}$ & $\begin{array}{l}\text { Lat } 40^{\circ} 38^{\prime} 48^{\prime \prime} \text {, long } 73^{\circ} 36^{\prime} 59^{\prime \prime} \text {, } \\
\text { Nassau County, } 20 \mathrm{ft} \text { down- } \\
\text { stream from bridge on } \\
\text { Foxhurst Road, at Baldwin. }\end{array}$ & $8-17-83$ & .85 \\
\hline 01310800 & $\begin{array}{l}\text { South Pond Outlet } \\
\text { at Rockville } \\
\text { Centre }\end{array}$ & $\begin{array}{l}\text { Lat } 40^{\circ} 40^{\prime} 00^{\prime \prime}, \text { long } 73^{\circ} 39^{\prime} 08^{\prime \prime} \\
\text { Nassau County, at bridge on } \\
\text { Lakeview Ave., } 0.75 \mathrm{mi} \\
\text { north of Rockville Centre. }\end{array}$ & $\begin{array}{r}12-1-81 \\
3-4-82 \\
5-3-82 \\
9-8-82 \\
1-25-83 \\
4-5-83 \\
7-19-83 \\
9-23-83\end{array}$ & $\begin{array}{l}0 \\
0 \\
0 \\
0 \\
0 \\
0 \\
.11\end{array}$ \\
\hline 01311200 & $\begin{array}{l}\text { Motts Creek at } \\
\text { Valley Stream }\end{array}$ & $\begin{array}{l}\text { Lat } 40^{\circ} 39^{\prime} 01^{\prime \prime}, \text { long } 73^{\circ} 42 / 45^{\prime \prime} \text {, } \\
\text { Nassau County, } 50 \mathrm{ft} \text { down- } \\
\text { stream from bridge on } \\
\text { Rosedale Road, } 1 \mathrm{mi} \text { south- } \\
\text { west of Valley Stream. }\end{array}$ & $\begin{array}{r}12-1-81 \\
3-4-82 \\
5-3-82 \\
9-8-82 \\
1-25-83 \\
4-5-83 \\
7-19-83 \\
9-23-83\end{array}$ & $\begin{array}{l}0 \\
0 \\
0 \\
0 \\
0 \\
1.2 \\
0 \\
0\end{array}$ \\
\hline 01311700 & $\begin{array}{l}\text { Valley Stream, } \\
\text { below West } \\
\text { Branch, at } \\
\text { Valley Stream }\end{array}$ & $\begin{array}{l}\text { Lat } 40^{\circ} 39^{\prime} 47^{\prime \prime}, \text { long } 73^{\circ} 42 \cdot 21^{\prime \prime}, \\
\text { Nassau County, } 200 \text { ft down- } \\
\text { stream from bridge on West } \\
\text { Valley Stream Blvd., at } \\
\text { village park in Valley } \\
\text { Stream, and } 500 \text { ft down- } \\
\text { stream from gaging station. }\end{array}$ & $\begin{array}{r}12-1-81 \\
3-4-82 \\
5-3-82 \\
9-8-82 \\
1-25-83 \\
4-5-83 \\
7-19-83 \\
9-23-83 \\
\end{array}$ & $\begin{array}{l}0 \\
0 \\
0 \\
0 \\
0 \\
0 \\
0 \\
0\end{array}$ \\
\hline
\end{tabular}


Stream discharge has been measured periodically at five sites in the area since the 1940's; locations of these sites are shown on plate 1A, and the discharge measurements are given in table 3. The U.S. Geological Survey maintains continuous gaging stations at two other sites--Pines Brook at Malverne and Valley Stream at Valley Stream (p1. 1A); daily discharges at these two sites from the 1940's to the present are available from the Survey's Long Island office in Syosset.

\section{SUMMARY}

Ground water is the sole source of water supply in the southwestern part of the Town of Hempstead and surrounding areas. Increased use of ground water has brought about the need for detailed knowledge of the underlying hydrogeologic system.

The area is underlain by Holocene, Pleistocene, and Upper Cretaceous deposits that consist of unconsolidated gravel, sand, silt, and clay; the deposits are divided into eight geologic units, which have a total maximum thickness of about 1,500 ft. Underlying these deposits is crystalline bedrock of early Paleozolc and(or) Precambrian age.

Precipitation is the only source of ground water in the area. The long-term average annual precipitation at the Valley Stream weather station during 1927-83 was 42.62 inches.

The water table has a maximum altitude in the northeastern part of the study area; the water-table altitude decreases to sea level along the southern shore. The potentiometric surface of the Magothy aquifer also has its maximum altitude in the northeastern part of the study area; the potentiometricsurface altitude decreases to $5 \mathrm{ft}$ below sea level along the southwestern shore.

\section{REFERENCES CITED}

Cohen, Philip, Franke, 0. L., and McClymonds, N. E., 1969, Hydrologic effects of the 1962-66 drought on Long Island, New York: U.S. Geological Survey Water-Supp1y Paper 1879-F, p. F1-F18.

Donaldson, C. D., and Koszalka, E. J., 1982a, Potentiometric surface of the Magothy aquifer, Long Island, New York, in March 1979: U.S. Geological Survey Open-File Report 82-160, 2 sheets.

1982b, Potentiometric surface of the Lloyd aquifer, Long Island, New York, in January 1979: U.S. Geological Survey Open-File Report $82-162,2$ sheets.

1982c, Water table on Long Island, New York, March 1979: U.S. Geological Survey Open-File Report 82-163, 2 sheets. 
Doriski, T. P., Potentiometric-surface altitudes of major aquifers on Long Island, New York, in 1983: U.S. Geological Survey Water-Resources Investigations Report 85-4321 (in press).

Doriski, T. P., and Wilde-Katz, Franceska, 1983, Geology of the 20-foot clay and Gardiners clay in southern Nassau and southwestern Suffolk Counties, Long Island, New York: U.S. Geological Survey Water-Resources Investigations $82-4056,17 \mathrm{p}$.

Fisher, D. W., and others, 1962, Geologic map of New York, Lower Hudson sheet, 1961: New York State Museum and Science Service, Map and Chart Series, no. $5,1: 25,000$.

Fuller, M. L., 1914, The geology of Long Island, New York: U.S. Geological Survey Professional Paper 82, $231 \mathrm{p}$.

Isbister, John, 1966, Geology and hydrology of northeastern Nassau County, Long Island, New York: U.S. Geological Survey Water-Supply Paper 1825, $89 \mathrm{p}$.

Jensen, H. M., and Soren, Julian, 1974, Hydrogeology of Suffolk County, Long Island, New York: U.S. Geological Survey Hydrologic Investigations Atlas HA-501, 2 sheets.

Koszalka, E. J., 1975, The water table on Long Island, New York, in March 1974: Long Island Water Resources Bulletin 5, 7 p.

Ku, H. F. H., Vecchioli, John, and Cerrillo, L. A., 1975, Hydrogeology along the proposed barrier-recharge-well alinement in southern Nassau County, Long Island, New York: U.S. Geological Survey Hydrologic Investigations At las HA-502, 1 sheet.

Lonnie, T. P., 1982, Mineral and chemical composition of clay beds on the south shore of Long Island, New York: Journal of Sedimentary Petrology, v. 52, no. 2 , p. 529-536.

Miller, J. F., and Frederick, R. H., 1969, The precipitation regime of Long Island, New York: U.S. Geological Survey Professional Paper 627-A, $21 \mathrm{p}$.

Nakao, J. H., and Erlichman, F. R., 1978, The water table on Long Island, New York, in March 1975: U.S. Geological Survey Open-File Report 78-569, $10 \mathrm{p}$.

Perlmutter, N. M., and Geraghty, J. J., 1963, Geology and ground-water conditions in southern Nassau and southeastern Queens Counties, Long Island, New York: U.S. Geological Survey Water-Supply Paper 1613A, $250 \mathrm{p}$.

Soren, Julian, 1978, Subsurface geology and paleogeography of Queens County, Long Island, New York: U.S. Geological Survey Water-Resources Investigations $77-34,17 \mathrm{p}$. 
Suter, Russe11, deLaguna, Wa1lace, and Perlmutter, N. M., 1949, Mapping of geologic formations and aquifers of the Long Island, New York: New York State Water Power and Control Commission Bulletin GW-18, 212 p.

Swarzenski, W. V., 1963, Hydrogeology of northwestern Nassau and northeastern Queens County, Long Island, New York: U.S. Geological Survey WaterSupply Paper 1657, 90 p.

U.S. Geological Survey, Water resources data for New York, Volume 2--Long Island, U.S. Geological Survey water-data report. (Issued annually.)

Veatch, A. C., Slichter, C. S., Bowman, Isaiah, Crosby, W. 0., and Horton, R. E., 1906, Underground water resources of Long Island, New York: U.S. Geological Survey Professional Paper 44, 394 p. 